\title{
ROLE OF LYMPH NODES IN ADJUVANT-INDUCED ARTHRITIS IN RATS
}

BY

\author{
B. B. NEWBOULD \\ From the Research Department, Imperial Chemical Industries Limited, \\ Pharmaceuticals Division, Alderley Park, Macclesfield, Cheshire
}

The arthritic syndrome induced in rats by an intradermal injection of a fine suspension of dead mycobacteria in liquid paraffin was first described by Stoerk, Bielinski, and Budzilovich (1954) and later studied in detail by Pearson $(1956,1959)$. The syndrome is characterized by the appearance of inflamed lesions, called secondary lesions, remote from the injection site after a delay of approximately 10 days. The mechanisms involved in the development of secondary lesions are still obscure. There is little evidence to support the idea that an infectious agent is involved (Sharp, Waksman, Pearson, and Madoff, 1961), although Jones and Ward (1963), from their histological studies, consider that this is still a possibility. It is also unlikely that an auto-immune mechanism resulting from tissue damage at the injection site is involved, since Ward and Jones (1962) showed that, whilst the development of secondary lesions was prevented by removing the depot within 2 hours of injecting adjuvant into the tail, removal after this time had no effect. Considerable evidence has been presented which suggests that secondary lesions are the result of a delayed hypersensitivity response to disseminated antigen which is probably derived from the injected tubercle bacilli (Waksman, Pearson, and Sharp, 1960). However, most of this evidence is indirect and little is known about the precise steps involved. Recently, it was shown that a pre-requisite for the development of secondary lesions was the presence of adjuvant in the lymphatic system (Newbould, 1964). Because of the association between lymph nodes and antibody production, regional lymph nodes may play an important role in the development of secondary lesions. Previous attempts to interfere with the development of secondary lesions by removal of the popliteal lymph node draining the injection site in the foot were unsuccessful (Waksman and others, 1960). However, adjuvant injected into the foot pad is disseminated to many nodes (Newbould, 1964). It therefore seemed likely that more lymph nodes would have to be removed before their significance in the development of the syndrome could be assessed.

The object of the work reported here was to study the effect of removal of draining lymph nodes on the development of secondary lesions when the nodes were removed at the time of injection of adjuvant and at intervals thereafter.

\section{Methods}

Animals.-Male, specific pathogen-free, albino rats, Alderley Park strain I, were used. They belonged to a colony-bred strain of rats of Wistar origin and weighed approximately $200 \mathrm{~g}$.

Production of Arthritis.-The arthritic syndrome was induced by an injection of $0.05 \mathrm{ml}$. of a fine suspension of dead tubercle bacilli in liquid paraffin B.P. $(5 \mathrm{mg} . / \mathrm{ml}$.) intradermally into the right hind foot-pad or intradermally into the middle of the right flank. Tubercle bacilli were derived from human strains, "PN", "DT", and "C", which were grown for 8 weeks, killed by steam, and dried in a vacuum oven. The development of the arthritic syndrome was followed by measuring with a micrometer, the swelling in the hind feet across a sagittal section (Newbould, 1963). The severity of secondary lesions was assessed in each rat as nil (0); mild (1); moderate (2); moderately severe (3); or severe (4). The figures in parenthesis were used to give the total secondary lesion score in each group of rats.

Removal of Lymph Nodes. - Lymph nodes were excised from rats anaesthetized with pentobarbitone and weighed on a torsion balance. They were named according to the nomenclature of Sanders and Florey (1940).

\section{Experiment 1}

Five groups of three rats were used. Lymph nodes were removed from the right side immediately before 
injection of adjuvant into the right hind foot-pad, as follows:

Group 1: Popliteal;

Group 2: Popliteal, inguinal, para-aortic;

Group 3: Popliteal, inguinal, para-aortic, renal and internal axillary;

Group 4: Nodes left intact but rats otherwise submitted to the same operative procedures as used in Group 3;

Group 5: No operation.

Fifteen days after injection, the total secondary lesion score, increase in thickness of the left hind-foot, change in body weight, and weights of the remaining lymph nodes were measured.

\section{Experiment $2 a$}

Eleven groups of four rats were injected with adjuvant into the right hind foot-pad on Day 0. On each of Days $1,3,5,7$, and 9 after injection, the popliteal, inguinal, para-aortic, renal, and internal axillary nodes were removed from the right side of four rats and weighed. At each of the above times the same lymph nodes were exposed in another group of four rats. These nodes were left intact and the incisions closed. One group of four rats was not operated upon. 15 days after injection secondary lesions were recorded as present or absent and the body weight change from Day 0 was assessed.

\section{Experiment $2 b$}

Eleven groups of four rats were injected with adjuvant intradermally into the middle of the right flank on Day 0 . On each of Days 1, 3, 5, 7, and 9 after injection, the right inguinal and internal axillary nodes were removed from four rats and weighed. At each of the above times the contralateral nodes were removed from another four rats. One group of four rats was not operated upon. 15 days after injection, secondary lesions were recorded as present or absent and the body weight change from Day 0 was assessed.

\section{Results}

Experiment 1.-Removal of the popliteal lymph node from the right leg before injection of adjuvant into the right hind foot-pad did not prevent the development of secondary lesions which were almost as severe as those in sham-operated or un-operated controls (Fig. 1). Secondary lesions, although less severe, developed in all rats from which the popliteal, inguinal, and para-aortic lymph nodes had been removed. However, when all the major lymph nodes draining the right injected site had been removed, secondary lesions failed to develop in two out of three rats, and in these two animals there was no increase in thickness of the left hind foot, and weight gain was appreciable. Thus, when nodes adjacent to the injection site are removed, other draining nodes, more remote, are still apparently involved in the development of secondary lesions and all must be removed to obtain complete inhibition. The rat which developed mild secondary lesions after having had all its draining nodes removed illustrates a phenomenon which has been repeatedly encountered. In this rat, collateral lymphatic connexions were apparently present, for the para-aortic node on the left side was grossly enlarged and weighed $120 \mathrm{mg}$. In contrast, the left para-aortic nodes from the other two rats in this group weighed 45 and $30 \mathrm{mg}$. respectively and those from the other rats in this experiment had a mean weight of $43 \mathrm{mg}$.

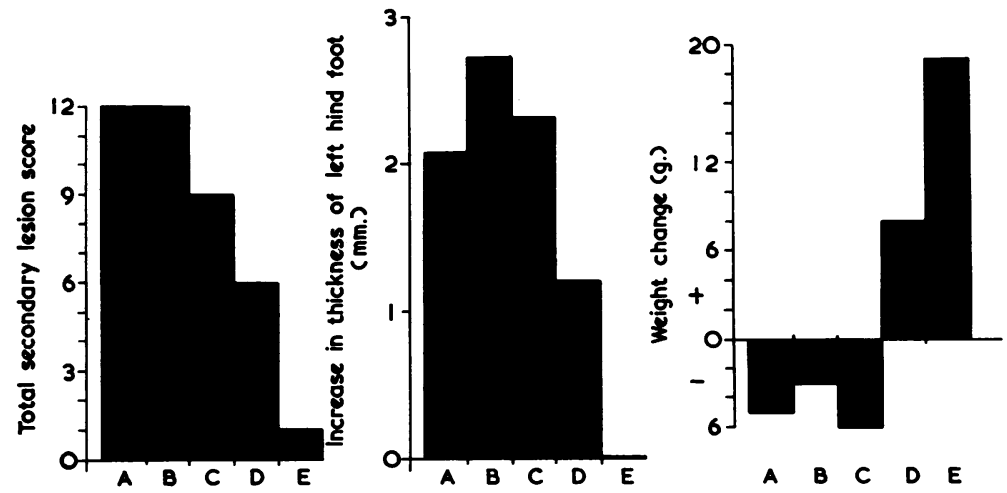

Fig. 1.-Total secondary lesion score, increase in thickness of the left hind foot, and body weight change of rats 15 days after the injection of adjuvant into the right hind foot-pad. Groups A to $\mathbf{E}$ each contained three rats.

$A=$ control (No operation)

$\mathbf{B}=$ control (Sham operation)

$\mathrm{C}=$ Popliteal node removed.

D = Popliteal inguinal para-aortic nodes removed.

$\mathbf{E}=$ Popliteal, inguinal, para-aortic, renal and internal axillary nodes removed.

Lymph nodes removed on Day 0 , just before injection. 
Experiment 2a.-In this experiment the draining lymph nodes were removed at intervals after injection of adjuvant into the foot pad. The majority of rats from which the lymph nodes were removed before Day 5 did not develop secondary lesions during the 15-day period of the experiment (Table I). However, all rats from which the draining nodes were removed after Day 5, i.e. on Days 7 and 9, developed secondary lesions on Day 10. The presence of secondary lesions was reflected in a loss of body weight.

The popliteal, inguinal, and para-aortic nodes, which are close to the injection site, increased rapidly in weight during the first 5 days (Fig. 2).

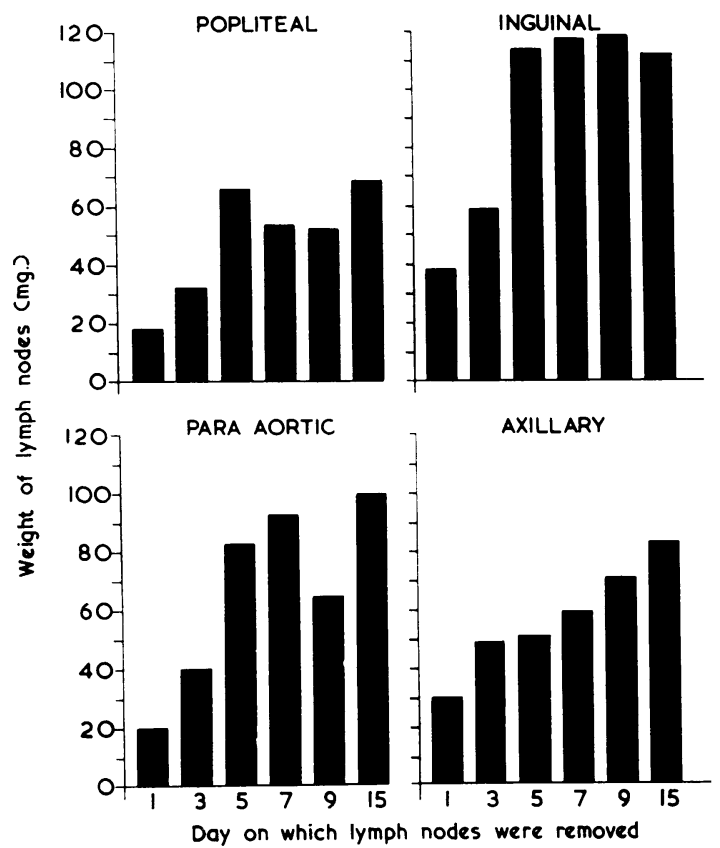

Fig. 2.-Weight of draining lymph nodes at intervals after injecting adjuvant into the foot pad. Each group contained four rats.
The weight of the internal axillary node, which is more remote from the injection site, increased gradually during the period of the experiment.

Experiment 2b.- To confirm the above observation, groups of rats were injected with adjuvant intradermally into the middle of the right flank and the inguinal and axillary nodes, which are the principal nodes draining this site, were removed at intervals after injection. As in Experiment $2 a$. removal of the draining nodes before Day 5 prevented the development of secondary lesions in all but one rat, whilst removal after Day 5 did not interfere with the development of the syndrome (Table II, opposite). The axillary node draining the injection site increased rapidly in weight during the first 7 days, whilst the weights of the contralateral axillary nodes remained relatively constant (Fig. 3, opposite).

\section{Discussion}

Waksman and others (1960) suggested that an immunological reaction is involved in the development of secondary lesions in rats injected with adjuvant intradermally. More recently, Waksman and Wennersten (1963) have suggested that this reaction is of the delayed or cellular type, because the syndrome could be passively transferred in inbred rats with suspensions of viable lymph node cells. The identity of the antigen is unknown, but it is thought to be a component of the tubercle bacillus which has become disseminated after injection.

The results obtained in the present study clarify the events which take place between the injection of adjuvant on Day 0 and the appearance of secondary lesions on Day 10. If all the draining lymph nodes are removed before the injection of adjuvant. secondary lesions fail to develop in most of the rats. Thus, lymph nodes draining the site into which

TABLE I

SECONDARY LESIONS AND WEIGHT CHANGES OF RATS FROM WHICH THE DRAINING LYMPH NODES HAVE BEEN REMOVED AT INTERVALS AFTER INJECTING ADJUVANT INTRADERMALLY INTO THE RIGHT HIND FOOT-PAD

\begin{tabular}{|c|c|c|c|c|}
\hline \multirow{2}{*}{$\begin{array}{l}\text { Day on which } \\
\text { Lymph Nodes } \\
\text { were Removed }\end{array}$} & \multicolumn{2}{|c|}{ Lymph Nodes Removed from Right (Injected) Side } & \multicolumn{2}{|l|}{ Sham-operated Controls } \\
\hline & $\begin{array}{l}\text { Number of Rats with Secondary Lesions } \\
\text { (Day 15) }\end{array}$ & $\begin{array}{c}\text { Mean } \\
\text { Weight Change } \\
\text { ( Day } 0-15)\end{array}$ & $\begin{array}{c}\text { Number of Rats with Secondary Lesions } \\
\text { (Day 15) }\end{array}$ & $\begin{array}{l}\text { Mean } \\
\text { Weight Change } \\
\text { (Day } 0-15)\end{array}$ \\
\hline $\begin{array}{c}1 \\
3 \\
5 \\
7 \\
9 \\
15 \\
\text { (No operation) }\end{array}$ & $\begin{array}{l}0 \\
1 \\
1 \\
4 \\
4 \\
4\end{array}$ & $\begin{array}{l}+21 \\
+5 \\
+10 \\
-6 \\
-4 \\
-19\end{array}$ & $\begin{array}{l}4 \\
4 \\
4 \\
4 \\
4\end{array}$ & $\begin{array}{l}-9 \\
-10 \\
-16 \\
-12 \\
-3\end{array}$ \\
\hline
\end{tabular}


TABLE II

SECONDARY LESIONS JAND WEIGHT CHANGES OF RATS FROM WHICH THE DRAINING LYMPH NODES HAVE BEEN REMOVED AT INTERVALS AFTER INJECTING ADJUVANT INTRADERMALLY INTO THE RIGHT FLANK

\begin{tabular}{|c|c|c|c|c|}
\hline \multirow{2}{*}{$\begin{array}{l}\text { Day on which } \\
\text { Lymph Nodes } \\
\text { were Removed }\end{array}$} & \multicolumn{2}{|c|}{ Lymph Nodes Removed from Right (Injected) Side } & \multicolumn{2}{|c|}{ Lymph Nodes Removed from Left Side } \\
\hline & $\begin{array}{l}\text { Number of Rats with Secondary Lesions } \\
\text { (Day 15) }\end{array}$ & $\begin{array}{c}\text { Mean } \\
\text { Weight Change } \\
\text { (Day 0-15) }\end{array}$ & $\begin{array}{l}\text { Number of Rats with Secondary Lesions } \\
\text { (Day 15) }\end{array}$ & $\begin{array}{c}\text { Mean } \\
\text { Weight Change } \\
\text { (Day 0-15) }\end{array}$ \\
\hline $\begin{array}{r}1 \\
3 \\
5 \\
7 \\
9 \\
15\end{array}$ & $\begin{array}{l}0 \\
0 \\
1 \\
4 \\
4 \\
4\end{array}$ & $\begin{array}{l}+67 \\
+33 \\
+33 \\
-7 \\
+7 \\
+9\end{array}$ & $\begin{array}{l}4 \\
4 \\
4 \\
4 \\
4\end{array}$ & $\begin{array}{l}+6 \\
-7 \\
+13 \\
+13 \\
-7\end{array}$ \\
\hline
\end{tabular}

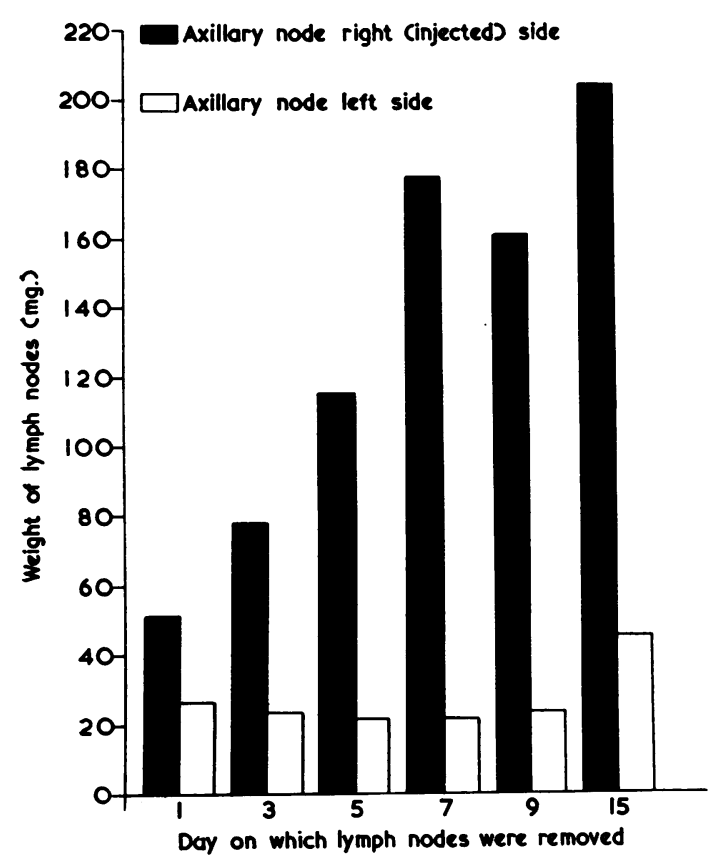

Fig. 3.-Axillary lymph node weights at intervals after injecting adjuvant into middle of right flank. Each group contained four rats.

adjuvant is injected are necessary for the development of secondary lesions. On the rare occasions when secondary lesions develop after all the draining lymph nodes have been removed, it is because adjuvant has become disseminated to at least one node on the contralateral side. If the draining lymph nodes are removed within 5 days of injection, secondary lesions do not develop on Day 10, but if they are removed on Day 7 the development of secondary lesions is unimpaired. It is concluded that the cells shown to be important by the passive transfer studies of Waksman and Wennersten (1963) may be released from the lymph nodes after Day 5 and that secondary lesions initiated at the time the cells are released, then take 5 days to become visible. These findings explain the results of Waksman and Wennersten (1963), for after passive transfer of viable lymph node cells taken from donors 7 days after injection of adjuvant, secondary lesions took from 4 to 8 days to become visible in the recipients.

The results of removing lymph nodes from rats injected with adjuvant resemble those recently published by Turk and Stone (1963) in a study of the role of draining lymph nodes in the development of hypersensitivity to chemical sensitizing agents in the guinea-pig. They found that removal of the draining nodes within 4 days of applying the sensitizing agent inhibited the development of skin sensitivity, whilst removal after 4 days had no effect. Studies of the cellular changes within the draining node 4 days after applying the sensitizer revealed a peak in the development of large pyroninophilic cells which they believe to be the precursors of immunologically competent lymphocytes involved in the skin reaction. In the development of the rat arthritis syndrome, the increase in weight of lymph nodes adjacent to the injection site may be a reflection of increased activity within the nodes. We are now investigating the cellular changes in the draining nodes of rats with adjuvant-induced arthritis to see if they are similar to those described by Turk and Stone (1963) in the draining lymph nodes of guinea-pigs made hypersensitive to chemical sensitizing agents.

\section{Summary}

Secondary lesions do not develop in rats if all the draining lymph nodes are removed within 5 days of injecting adjuvant into the foot-pad or flank. If the nodes are removed on Day 7 , the development of secondary lesions is not impaired. Draining lymph nodes increase in weight most rapidly during the first 5 to 7 days after injection. 
I wish to express my gratitude to Miss $\mathrm{S}$. Warrington and Mr. R. Siddall for their technical assistance. The dead tubercle bacilli were supplied by the Ministry of Agriculture Veterinary Laboratories, Weybridge, Surrey.

\section{REFERENCES}

Jones, R. S., and Ward, J. R. (1963). Arthr. and Rheum., 6, 23.

Newbould, B. B. (1963). Brit. J. Pharmacol., 21, 127.

- (1964). Brit.J. exp. Path., 45 (in press).

Pearson, C. M. (1956). Proc. Soc. exp. Biol. (N.Y.), 91, 95 .

- (1959). In "Mechanisms of Hypersensitivity", ed. J. H. Shaffer, G. A. LoGrippo, and M. W. Chase, p. 647. (Henry Ford Hospital, International Symposium, 1958). Little, Brown and Co., Boston.

Sanders, A. G., and Florey, H. W. (1940). Brit. J. exp. Path., 21, 275.

Sharp, J. R., Waksman, B. H., Pearson, C. M., and Madoff, S. (1961). Arthr. and Rheum., 4, 169.

Stoerk, H. C., Bielinski, T. C., and Budzilovich, T. (1954). Amer. J. Path., 30,616.

Turk, J. L., and Stone, S. H. (1963). In "Cell-bound Antibodies", ed. B. Amos and H. Koprowski, p. 51. Wistar Institute Press, Philadelphia.
Waksman, B. H., Pearson, C. M., and Sharp, J. T. (1960). J. Immunol., 85, 403.

—_ and Wennersten, C. (1963). Int. Arch. Allergy, 23, 129.

Ward, J. R., and Jones, R. S. (1962). Arthr. and Rheum., $5,557$.

Rôle des ganglions lymphatiques dans l'arthrite provoqué par l'adjuvant chez le rat

RÉSUMÉ

Des lésions sécondaires ne se développent pas chez le rat lorsqu'on extirpe tous les ganglions lymphatiques de drainage en dedans de 5 jours qui suivent une injection de l'adjuvant dans la patte ou dans le flanc. Si l'on extirpe les ganglions le 7-ème jour, le développement des lésions secondaires n'est pas empêché. Le poids des ganglions lymphatiques de drainage augmente le plus rapidement entre le 5 -ème et le 7-ème jour après l'injection.

El papel de los ganglios linfáticos en la artritis provocada por el coadyuvante en la rata Sumario

Lesiones secundarias no se desarrollan en la rata cuando se extirpa todos los ganglios linfáticos de drenaje dentro de 5 días que siguen una inyección del coadyuvante en la pata o en el flanco. Cuando se extirpa los ganglios el septimo día, el desarrollo de lesiones secundarias no se ve impedido. El peso de los ganglios linfáticos de drenaje aumenta lo más rápidamente entre el quinto y el septimo día después de la inyección. 